thymectomy and bursectomy on precipitin and natural hemagglutinin and production in the chicken. J. Immunol., 90: 878 (1963).

12. Harris, T. N., Rhoads J., and Stokes, J. J.: A study of the role of the thymus and spleen in the formation of antibiotics in the rabbit. J. Immunol., 58: 27 (1948).

13. Humphrey, J. H., Parrott. D. M. V., and East, J.: Studies on globulin and antibody production in mice thymectomized at birth. J. Immunol., 7: 419 (1964).

14. Isakovic, K., and Jankovic, B. D.: Role of the thymus and the bursa of Fabricius in immune reactions in chickens. II. Cellular changes in lymphoid tissues of thymectomized, bursectomized and normal chickens in the course of first antibody response. Int. Arch. Allergy Appl. Immunol., 24: 296 (1964).

15. Jankovic, B. D., and Isakovic, K.: Role of the thymus and bursa of Fabricius in immune reactions in chickens. I. Changes in lymphoid tissues of chickens surgically thymectomized at hatching. Int. Arch. Allergy Appl. Immunol., 24: 278 (1964).

16. Kincade, P. W., and Cooper, M. D.: Development and distribution of immunoglobulin-containing cells in the chicken. J. Immunol., 106: 371 (1971).

17. Lawton, A. R., Kincade, P. W., and Cooper, M. D.: Sequential expression of germ line germs in development of immunoglobulin class diversity. Fed Proc., 34: 33 (1975)

18. Lopez, V., Davies, S. D., and Smith J. J.: Studies in infantile marasmus. IV. Impairment of immunologic responses in the marasmic pig. Pediat. Res., 6: 779 (1972).

19. Mueller, A. P. Wolfe, H. R., and Meyer, R. K.: Precipitin production in chickens. XXI. Antibody production in bursectomized chickens and in chickens injected with 19-nortestosterone on the fifth day of incubation. J. Immunol., 85 : 172 (1960).

20. Mueller, A. P.. Wolfe, H. R., Meyer, R. K., and Aspinall, R. L.: Further studies on the role of the bursa of Fabricius in antibody production. J. Immunol., 88: 354 (1962).

21. Sainte-Marie, G. J.: A paraffin embedding technique for studies employing immunofluorescence. Histochem. Cytochemi., 10: 250 (1962).
22. Smythe, P. M., Schonland, M., Brereton-Stites, G. G., Coovadia, H. M., Grace H. J., Loening, W. E. K., Mafoyane, A., Parent, M. A., and Vox, G. H.: Thymolymphatic deficiency and depression of cell-mediated immunity in protein-calorie malnutrition. Lancet, $i: 939$ (1971).

23. Stecher, V. J., and Thorbecke, G. J.: Sites of formation of $\mathrm{C}_{3}{ }_{3}$. III. ${ }^{\mathrm{B}} \mathrm{IC}$ and immune globulin formation by tissues from serum-free and normal animals of various ages. Immunology, I2: 475 (1967).

24. St. Geme, J. W., Jr., Davis, C. W. C., Peralta, H. J., Farias, N. E., Yamauchi, T., and Cooper, M. D.: The biologic perturbations of persistent embryonic mumps virus infection. Pediat. Res., 7: 541 (1973).

25. St. Geme, J. W. Jr., Peralta, H., Farias, E., Davis, C. W. C., and Noren, G. R.: Experimental gestational mumps virus infection and endocardial fibroelastoris. Pediatrics, 48: 821 (1971).

26. Thorbecke, G. J., Warner, N. L., Hochwald, G. M and Ohanian, S. H. Immune globulin production by the bursa of Fabricius of young chickens. Immunology. 15: 123 (1968).

27. Williamson, A. P., Blattner, R. J., and Simonsen, L.: Cataracts following mumps virus in early chick embryos. Proc. Soc. Exp. Biol. Med., 96: 224 (1957).

28. Wistenholme, G. E. W., and Porter, R. (Eds.): Some Observations on Immunologic Response in the Thymus: Experimental and Clinical Studies (Little, Brown and Company, Boston, 1966).

29. Yamauchi, T., St. Geme, J. W., Jr., Oh, W., and Davis, C. W. C.: The biological and biochemical pathogenesis of mumps virus-induced embryonic growth retardation. Pediat. Res., 9: 30 (1975).

30. The authors wish to express their gratitude to Ms. Jenny Keshishian and Ms. Janice White in preparing this manuscript.

31. Portions of this paper were presented at the annual meeting of the American Pediatric Society and the Society for Pediatric Research, May 2, 1974 Washington, D.C.

32. Requests for reprints should be addressed to: T. Yamauchi, M.D., Arkansas Children's Hospital, 804 Wolfe St.. Little Rock, Ark. 72201 (USA).

33. Accepted for publication May 31, 1976.
Alanine aminotransferase arginase

fetus glutamate dehydrogenase liver thymidine kinase

\title{
Glutamate Dehydrogenase, Alanine Aminotransferase, Thymidine Kinase, and Arginase in Fetal and Adult Human and Rat Liver
}

\author{
ANNEMARIE HERZFELD, ${ }^{(19)}$ VICTOR M. ROSENOER, AND SUZANNE M. RAPER \\ Department of Biological Chemistry, Harvard Medical School: Cancer Research Institute, New England Deaconess \\ Hospital; Department of Gastroenterology, Lahey Clinic Foundation, Boston, Massachusetts, USA
}

\section{Extract}

In fetal livers of both man and rat thymidine kinase activity was 12 times higher than in the adult, glutamate dehydrogenase and arginase were present at $20-50 \%$ of their adult values, whereas alanine aminotransferase activity was only an insignificant fraction of that in the adult. Although the developmental changes for the four enzymes were quantitatively similar in both species, qualitatively there were some significant differences.

In adult human liver, glutamate dehydrogenase activity was distributed almost equally between the cytosol and particles; the concentration of only the soluble enzyme increased after birth. In rat liver, glutamate dehydrogenase remained exclusively a particulate enzyme. The soluble hepatic alanine aminotransferase activity rose in both species after birth (from less than $2 \mathrm{U} / \mathrm{g}$ to $41-57 \mathrm{U} / \mathrm{g}$, respectively). Thymidine kinase was wholly soluble in the fetal livers; only in adult human liver was additional activity (at least
$50 \%$ of the total) found in the particles. Arginase isozymes, identical and apparently the same single isozyme in fetal and adult rat liver, show an ontogenetic change in man. A shift from a single form, common to human fetal liver and fetal kidney, to at least two variants in adult human liver, indicates another complexity of the fully differentiated liver in man.

\section{Speculation}

It is unlikely that the occurrence of particulate thymidine kinase and soluble glutamate dehydrogenase in man is restricted to liver. Their relatively late appearance in life suggests that their further study would be of interest to both ontogeny and phylogeny.

The developmental formation of thymidine kinase (EC. 2.7.1.75), glutamate dehydrogenase (EC. 1.4.1.2), arginase (EC. 
3.5.3.1), and alanine aminotransferase (EC. 2.6.1.2) in rat liver has been studied extensively in this laboratory $(2,4-7,11)$. Thymidine kinase, required to synthesize a precursor of DNA, has high activity between the 15th and the 19th day of gestation and declines rapidly thereafter $(11)$. Arginase $(4,8)$ and glutamate dehydrogenase $(5,7)$, concerned in the metabolism of ammonia by furnishing urea for excretion or by scavenging ammonia for amino acid synthesis from $\alpha$-ketoglutarate, respectively, rise during late fetal life. Alanine aminotransferase (previously named glutamate pyruvate transaminase, GPT) accumulates only in the latter part of the suckling period (2). We have now determined the activities of these enzymes in human fetal and adult livers and found that, as in the rat, in human liver thymidine kinase was more concentrated in the fetus whereas the other enzymes increased with age. There were, however, qualitative differences in these enzymes.

For all four enzymes the adult human liver shows more diversity than the rat liver; the particulate alanine aminotransferase, a significant component only in fetal liver in the rat, persisted into adulthood in man. Glutamate dehydrogenase, thymidine kinase, and arginase, although maintaining the isozymes of fetal liver, all acquired an additional hepatic variant in the human adult liver. Such a shift from a single form in the fetal liver, to at least two variants in the adult human liver, indicates the increased complexity of the fully differentiated liver in man.

\section{MATERIALS AND METHODS}

Tissues from dead fetuses (between the 12th and the 20th weeks of gestation), aborted by hysterotomy or prostaglandin infusion, were obtained through the courtesy of Dr. S. Driscoll, Boston Hospital for Women, Boston, Massachusetts. An autopsy sample from a week-old infant was received through the courtesy of Dr. W. Taeusch, Boston Hospital for Women, for diagnostic purposes. Adult liver samples were portions of biopsy specimens taken for diagnostic purposes during surgery. Rats (males, 80-90 days old) were inbred albinos of the $\mathrm{Kx}$ strain. Fetal ages of rats were determined from the correlation between body weight and age according to the method of Gonzalez (1).

Tissue preparations, made within an hour after dissection, were identical for human and rat tissues. All manipulations were performed as rapidly as possible with reagents kept at $0^{\circ}$. Minced livers were homogenized in 9 volumes cold $0.15 \mathrm{M} \mathrm{KCl}$ (or, for arginase assays, in $56 \mathrm{mM} \mathrm{MnCl} \mathrm{M}_{2}-50 \mathrm{mM}$ imidazole buffer, $\mathrm{pH}$ 7.4) in glass-Teflon homogenizers and centrifuged for $30 \mathrm{~min}$, at $100,000 \times g$ to obtain soluble and particulate fractions. The pellets were resuspended to the original volume in $0.15 \mathrm{M} \mathrm{KCl}$ containing Triton X-100 to a final concentration of $0.5 \%$ and kept at $0^{\circ}$ for 30 min.

All quantitative enzyme determinations were made under conditions found to be optimal for rat liver. The spectrophotometric assays for glutamate dehydrogenase (5) and alanine aminotransferase $(14,15)$ have been described. Ammonia-free mixtures served as blanks for the glutamate dehydrogenase reactions; absorbances of alanine-free blanks were subtracted from the experimental alanine aminotransferase values. Both the cytosols and the Tritontreated particles were tested for glutamate dehydrogenase and alanine aminotransferase activities. Thymidine kinase assays were performed as described by Machovich and Greengard (11) on cytosols and whole homogenates after treatment with Triton. Blanks consisted of nonincubated complete mixtures. The activation, quantitative measurements of arginase activities, antibody titrations, and polyacrylamide gel electrophoresis of cytosolic fractions have been described $(8,13)$. Soluble extracts from livers or whole kidneys were prepared after heat activation of the whole homogenates and were used for electrophoresis and antibody titrations.

Enzyme activities are expressed as units (micromoles, or, in the case of thymidine kinase, nanomoles, product per min) per g liver. Protein concentrations were determined by the method of Lowry et al. (10).

\section{RESULTS}

Between 11.5 and 19 weeks of gestation, no major changes in the activities of arginase, alanine aminotransferase, or thymidine kinase occurred in human liver (Table 1). The method of abortion did not affect the activities of the enzymes. Present data are not sufficient to interpret the apparent decline of glutamate dehydrogenase activity in the second trimester. Enzyme activities in human liver during gestation (Table 1) are to be considered in the light of the developmental formation of the same enzymes in rat liver (Fig. 1). For comparisons of fetal activities in man and rat those fetal

Table 1. Enzyme activities in human fetal and adult livers ${ }^{1}$

\begin{tabular}{|c|c|c|c|c|c|c|c|}
\hline & \multicolumn{7}{|c|}{ Enzyme activity, $\mathrm{U} / \mathrm{g}$} \\
\hline & $\begin{array}{l}11.5 \\
\text { wks } \\
(\mathrm{H})\end{array}$ & $\begin{array}{c}14 \\
\text { wks } \\
(H)\end{array}$ & $\begin{array}{c}16 \\
\text { wks } \\
(P)\end{array}$ & $\begin{array}{c}17 \\
\text { wks } \\
(\mathrm{P})\end{array}$ & $\begin{array}{c}18 \\
\text { wks } \\
(\mathrm{H})\end{array}$ & $\begin{array}{c}19 \\
\text { wks } \\
(\mathrm{P})\end{array}$ & Adult \\
\hline Arginase (total) & 2 & 2 & 789 & 447 & 580 & 558 & $\begin{array}{c}1,382 \pm 103 \\
\text { (3) }\end{array}$ \\
\hline $\begin{array}{l}\text { Glutamate } \\
\text { dehydrogenase } \\
\text { (total) }\end{array}$ & 2 & 38.8 & 30.5 & 18.7 & 16.9 & 16.7 & $\begin{array}{c}46.2 \pm 6.8 \\
(4)\end{array}$ \\
\hline $\begin{array}{l}\text { Alanine amino- } \\
\text { transferase } \\
\text { (total) }\end{array}$ & 5.0 & 20.3 & 2 & 8.1 & 8.3 & 2.9 & $\begin{array}{c}46.6 \pm 9.8 \\
\text { (3) }\end{array}$ \\
\hline $\begin{array}{l}\text { Thymidine } \\
\text { kinase } \\
\text { (soluble) }\end{array}$ & 9.9 & 21.0 & 21.7 & 7.8 & 16.2 & 24.3 & $\begin{array}{c}1.25 \pm 0.53 \\
(6)\end{array}$ \\
\hline
\end{tabular}

${ }^{1} \mathrm{H}$ : hysterotomy; $\mathbf{P}$ : prostaglandin infusion. Adult activities are averages of three to six biopsy samples of "normal liver" (number of samples in parentheses) $\pm 1 \mathrm{SD}$. For values of the simultaneously assayed standard tissue (adult rat liver) see Table 2.

${ }^{2}$ No measurements were made.

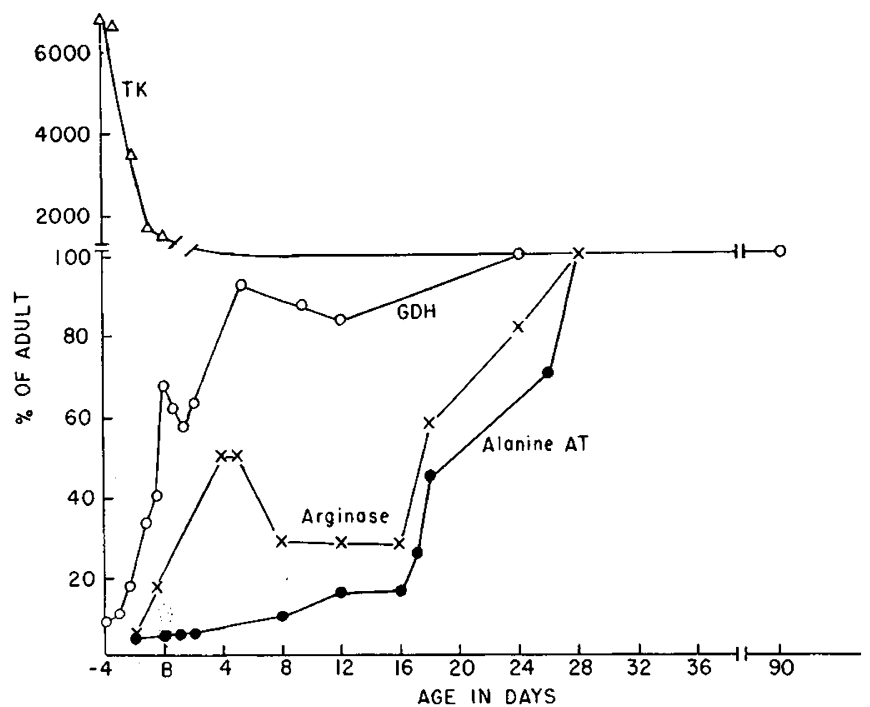

Fig. 1. The developmental formation of glutamate dehydrogenase, alanine aminotransferase, arginase, and thymidine kinase in rat liver. Changes with age in rat liver of mitochondrial glutamate dehydrogenase $(G D H)(\mathrm{O}-\mathrm{O})$, soluble alanine aminotransferase $(A T)(\bullet-\bullet)$, total arginase $(\times-\times)$, and soluble thymidine kinase $(T K)(\triangle-\triangle)$ activities are expressed as percentages of adult activities. The curves for glutamate dehydrogenase, arginase, and thymidine kinase were recalculated from previously published studies $(7,4,11)$ and that for alanine aminotransferase was partially transcribed from the report of Greengard (2) with new fetal values added. In adult rat liver activities for glutamate dehydrogenase were $45 \pm 6 \mathrm{U} / \mathrm{g}$, for alanine aminotransferase $55.1 \pm 3.3$ $\mathrm{U} / \mathrm{g}$, for arginase $2,545 \pm 278 \mathrm{U} / \mathrm{g}$, and for thymidine kinase $0.59 \pm 0.12$ $\mathrm{U} / \mathrm{g}$. Note break in ordinate above $100 \%$. 
ages in rat were chosen which illustrate the onset of prenatal rises in glutamate dehydrogenase and arginase activities while still showing elevated thymidine kinase and constant but low alanine aminotransferase activities (e.g., 1-2 days before birth).

Total glutamate dehydrogenase activity in fetal human liver was about $75 \%$ of that in the liver of the adult. Table 2 shows that in human adult liver the amount of soluble glutamate dehydrogenase activity represented a much greater fraction $(40 \%)$ of the total enzyme than in fetal or neonatal human liver (less than $3 \%$ ) or in rat liver at any age. The concentration of human particulate glutamate dehydrogenase was similar in fetal and adult liver (when all fetal values were combined and averaged). In rat the glutamate dehydrogenase concentration in adult liver was twice that of livers during late gestation.

In fetal and neonatal livers of both man and rat the particulate alanine aminotransferase comprised the major fraction of the total activity; the soluble enzyme catalyzed less than $20 \%$ of the total activity. The reverse was true in adults of both species. There the major fraction of the total hepatic alanine aminotransferase was cytosolic. In human liver the concentration of the particulate alanine aminotransferase was maintained in the adult, whereas in rat liver the particulate form decreased to insignificant levels soon after birth.

Thymidine kinase activities, known to be higher in fetal rat liver than in any normal tissue (11), were also higher in human fetal liver than in the adult (Table 2). In fetal livers of man and rat all of the activity was cytosolic and lower enzyme activities were obtained when whole homogenates were tested. In contrast, about half of the total thymidine kinase activity in adult human liver was particle bound. Treatment of homogenates or cytosol with Triton $\mathrm{X}-100$ did not activate thymidine kinase in adult liver.

Table 2 also shows the similarity in the protein concentration of human and rat livers; in human fetal liver, soluble protein represented a slightly higher fraction of the total protein than in rat, but in both species soluble protein concentration rose with age.

It has been reported before (12) that arginase activity in human fetal liver is about $40-50 \%$ that in the adult. We confirmed these results between the 16th and 20th week of gestation $(593 \pm 143$ $\mathrm{U} / \mathrm{g}$ in fetal and $1,382 \pm 103 \mathrm{U} / \mathrm{g}$ in adult human liver). Electrophoreses in anodic and cathodic directions of extracts from rat tissues have demonstrated that livers (adult and fetal) (and submaxillary gland) contain a variant of arginase (isozyme III) not found in any other adult rat tissue (8). Under the same electrophoretic conditions, arginase of other rat tissues was resolved into two variants (isozymes I and II), neither of which could be detected in rat liver (8). Figure 2 shows the arginase activities, determined in successive gel slices, after anodic (Fig. 2A) and cathodic (Fig. 2B) electrophoresis of human liver (fetal and adult) and of human fetal kidney. Extracts from adult rat kidney and liver were included in the same electrophoretic runs and the characteristic arginase isozymes (I and II for rat kidney and III for rat liver) are here shown as markers for known arginase variants (8) and to indicate the relative amounts of each isozyme in a tissue. Human liver arginase (fetal and adult) was indistinguishable from rat liver arginase by anodic electrophoresis. Arginase from human fetal kidney showed a small component (about $10 \%$ of the total activity) which corresponded to rat arginase isozyme I (kidney type), but the major activity, like that of hepatic arginase, did not move from the origin ( $c f$. rat arginase II and III). On cathodic electrophoresis (Fig. $2 B$ ), which resolves the basic proteins, rat hepatic arginase moved toward the cathode (isozyme III) whereas all the rat kidney arginase remained at the origin (isozymes I and II). About $65 \%$ of the adult human hepatic arginase moved similarly to rat isozyme III (with slight further spreading toward the cathode) and the remaining activity was located in the gel segment intermediate between the origin and isozyme III. No activity remained at the origin (no isozymes I and II). The intermediate zone of activity, migrating more slowly than isozyme III but faster than isozyme I or II (immobile in the cathodic system) was the only peak of arginase activity in human fetal liver. It was common to livers at both ages. However, in fetal human kidney $10 \%$ more of the total activity was found at the origin than in human fetal liver, confirming the small, but apparently significant peak of isozyme I seen in the anodic system. Neither fetal tissue contained any activity corresponding to isozyme III. Only cathodic electrophoresis revealed this difference between the arginases of fetal liver in man and rat; in livers of both species essentially all of the arginase was recovered in a single peak, but in the human fetal liver it did not migrate with the major component of adult liver.

Incubations of the adult human liver arginase with antiserum against rat liver arginase confirmed the similarity between human adult hepatic arginase (electrophoretically like rat isozyme III) and the rat liver arginase. Arginase from rat liver (and submaxillary gland) but not from any other adult rat tissue was inactivated by serum prepared against purified rat liver arginase $(8,13)$. Table 3 shows that $80 \%$ of the arginase from adult human liver was inactivated by the antiserum. This observation was consistent with the co-incidence, on electrophoresis, of $65 \%$ of the adult human liver arginase with the single isozyme of rat liver. Thus the additional arginase formed after the second trimester in human liver (but not in rat liver) was qualitatively different from the early non-tissue-specific form found in human fetal liver and kidney electrophoretically.

\section{DISCUSSION}

Before discussing significant qualitative differences in glutamate dehydrogenase, alanine aminotransferase, thymidine kinase, and arginase in fetal and adult livers of man and rat, it is important to stress the similarities in the developmental formation of the four

Table 2. Enzyme activities (units per $\mathrm{g}$ ) and protein concentration in fetal and adult human and rat livers ${ }^{1}$

\begin{tabular}{|c|c|c|c|c|c|c|c|c|}
\hline \multirow{2}{*}{ Liver } & \multicolumn{2}{|c|}{ Glutamate dehydrogenase, $\mathrm{U} / \mathrm{g}$} & \multicolumn{2}{|c|}{ Alanine aminotransferase, $\mathrm{U} / \mathrm{g}$} & \multicolumn{2}{|c|}{ Thymidine kinase, $\mathrm{U} / \mathrm{g}$} & \multicolumn{2}{|c|}{ Protein, mg/g } \\
\hline & Soluble & Particulate & Soluble & Particulate & Soluble & Particulate & Soluble & Particulate \\
\hline \multicolumn{9}{|l|}{ Human } \\
\hline Fetal & $0.45 \pm 0.1(3)$ & $29.7 \pm 17(6)$ & $1.86 \pm 0.73(9)$ & $6.9 \pm 7.0(5)$ & $15.3 \pm 8.2(10)$ & $0(3)$ & $63.5 \pm 7.5(4)$ & $76.5 \pm 7.5(4)$ \\
\hline Newborn & 1.9 & 41.2 & 1.7 & 2 & 0.72 & 3.59 & 48 & 52 \\
\hline Adult & $18.5 \pm 5.4(3)$ & $29.4 \pm 9.2(3)$ & $41.3 \pm 18(3)$ & $5.3 \pm 1.2(3)$ & $1.43 \pm 0.67(8)$ & $1.9 \pm 0.9(4)$ & $93.0 \pm 5.0(4)$ & $94 \pm 16(4)$ \\
\hline Adult & $2.4 \pm 1.6(4)$ & $46.8 \pm 10.7(9)$ & $57.5 \pm 8.0(10)$ & $3.5 \pm 3.3(10)$ & $0.59 \pm 0.12(7)$ & $0(7)$ & $91 \pm 13$ & $123 \pm 15$ \\
\hline
\end{tabular}

${ }^{1}$ Fetal rats were used between the 20th-21st days of gestation for glutamate dehydrogenase, alanine aminotransferase, and protein assays. Values for thymidine kinase activities (19th day of gestation) were transcribed from Machovich and Greengard (11). Values for rat liver proteins were obtained from Knox (9). Results are given as the mean \pm 1 SD (number of samples in parentheses).

${ }^{2}$ No measurements were made. 


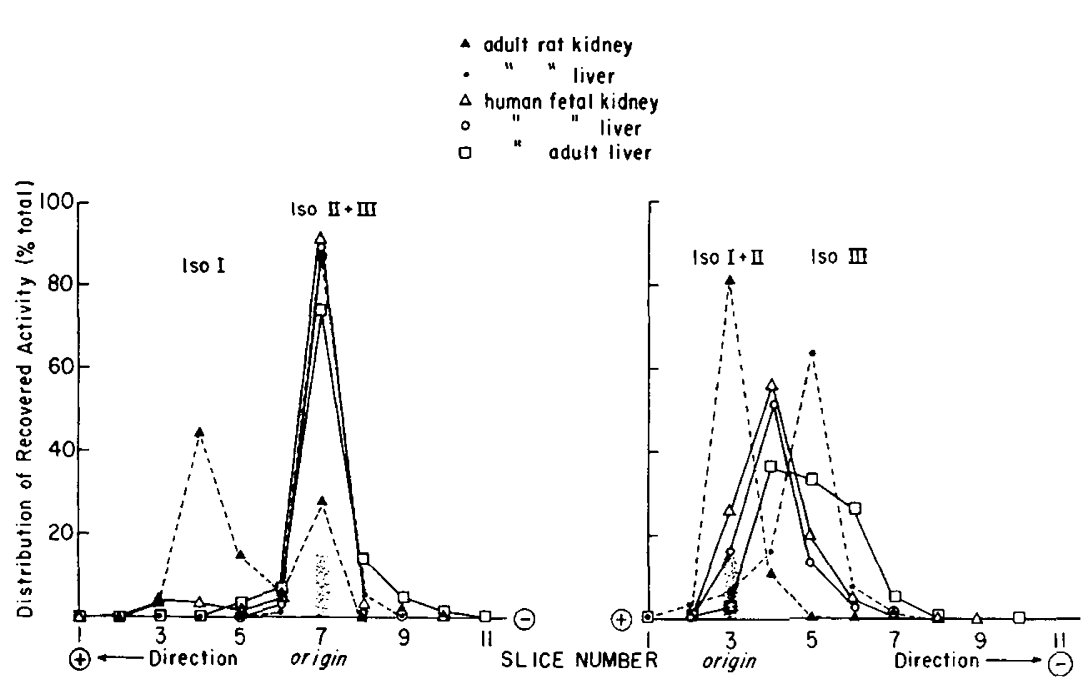

Fig. 2. Arginase activities in gel segments after anodic $(A)$ and cathodic $(B)$ electrophoresis. Arginase extracts from adult rat kidney $(\mathbf{A})$, rat liver $(\boldsymbol{O})$, adult human liver $(\square)$, fetal human liver $(O)$, and fetal human kidney $(\triangle)$ were subjected to anodic $(A)$ and cathodic $(B)$ electrophoresis as described by Herzfeld and Raper (8). Duplicate samples placed in the gels contained $0.4 \mathrm{U}$ human or rat liver arginase, $0.35 \mathrm{U}$ rat kidney, and $0.18 \mathrm{U}$ fetal human kidney arginase. Recoveries ranged between $60 \%$ and $80 \%$ for all tissues. The abscissa denotes sequential 0.5 -cm gel slices, numbered in the anodic direction. "Origin" refers to the sample gel in which the tissue extract was incorporated. The ordinate shows the percentage of recovered activity found in each gel slice. Isozymes I-III were described in a previous report (8). Arginase activities were 1,154 U/g (adult human liver), $380 \mathrm{U} / \mathrm{g}$ (fetal human liver), 18.6 $\mathrm{U} / \mathrm{g}$ (fetal human kidney), 2,300 U/g (rat liver), and $46.7 \mathrm{U} / \mathrm{g}$ (rat kidney) in the cytosol fractions used for electrophoresis.

Table 3. Inactivation of arginases by serum against rat liver arginase

\begin{tabular}{lllll}
\hline & & \multicolumn{2}{c}{$\begin{array}{c}\text { Enzyme activity ( } \mu \text { mol/assay) } \\
\text { after incubation with } 50 \mu \mathrm{l}\end{array}$} \\
\cline { 3 - 5 } Species & Tissue & Initial & $\begin{array}{c}\text { Control } \\
\text { serum }\end{array}$ & Antiserum \\
\hline Rat & Liver & 1.85 & 1.80 & 0.01 \\
Rat & Kidney & 1.50 & 1.49 & 1.58 \\
Man & Liver & 3.30 & 3.29 & 0.65 \\
\hline
\end{tabular}

${ }^{1}$ Total arginase activity in adult human liver was $1,337 \mathrm{U} / \mathrm{g}$. Soluble tissue extracts were incubated for $45 \mathrm{~min}$ at $37^{\circ}$ with $50 \mu 1$ control rabbit serum or antiserum against rat liver arginase. After precipitation by centrifugation of the complex formed, arginase activity was determined in the supernatants as described $(8,14)$.

enzymes in the two species. In both, thymidine kinase concentration in fetal liver greatly exceeded that in the adult; in both, glutamate dehydrogenase and arginase accumulations began well before birth and in both species only traces of alanine aminotransferase activity were found before birth. Thus species-specific qualitative differences in these enzymes were discerned against a common framework of similar quantitative developmental changes. The emergence of different forms of the enzymes later in human development was superimposed on the non-species-specific general background of common enzyme appearance. For all four enzymes, the adult human liver contained new variants.

Glutamate dehydrogenase in rat tissues has long been used as a mitochondrial marker enzyme. The present results indicate that in the adult human liver, glutamate dehydrogenase activity is not the exclusive property of mitochondria; only in the fetal liver was all the glutamate dehydrogenase activity confined to particles at concentrations similar to those in the adult. This constancy of mitochondrial glutamate dehydrogenase in fetal and adult livers contrasts with the sudden accumulation, late in gestation, of the enzyme in rat liver (see Fig. 1). It must again be stressed, however, that in both species the total activity (cytosolic and mitochondrial) increased significantly with age. The major ontogenetic difference in the enzyme between man and rat lies in the emergence, after birth, of cytosolic glutamate dehydrogenase. (The single neonatal value, obtained from autopsy of a week-old baby, suggests that the rise in cytosolic glutamate dehydrogenase does not occur immediately after birth. This finding, however, must be viewed with caution since it is based on only a single observation in a child who did not survive the early neonatal period.) The stimulus evoking the appearance in adult liver of a delayed species-specific activation of a gene product is presently unknown.

The differences in the subcellular distribution of alanine aminotransferases in livers of man and rat are subtle. In both species most of the enzyme activity is cytosolic and virtually absent from fetal and neonatal livers. The small fraction of the alanine aminotransferase activity which is particulate, however, persists in man whereas it decreases significantly with age in rat.

Taylor et al. (16) have demonstrated previously that different isozymic forms of thymidine kinase occur in human fetal and adult livers. The authors reported that fetal (cytosolic) thymidine kinase differs from the adult enzyme in electrophoretic migration, specificity of phosphate donors, inhibition by deoxycytidine triphosphate, inactivation by heat, and resistance to low $\mathrm{pH}$. Unfortunately, their data do not show any absolute activities of either the soluble or the particulate thymidine kinase. Our results demonstrate that thymidine kinase activities in fetal livers of man and rat were much higher than in adult livers. In the fetus the hepatic enzyme in man and rat was confined to the cytosol without a trace of activity in particles. In man, a week after birth, the shift to the adult pattern of subcellular distribution had already occurred. With thymidine kinase, as with glutamate dehydrogenase, the mature human liver exhibited a new variant of the enzyme that was virtually absent from the mature rat liver and whose specific physiologic function is unknown.

The developmental formation of total arginase, as was true for the three enzymes discussed above, differed only in detail in human and rat liver. The major disparity between the enzymes of the two species was qualitative. Whereas the hepatic rat arginase contained the same, single variant of arginase (isozyme III) in the fetal and the adult liver, human liver arginase underwent a proliferation of isozymes in the course of maturation. The single isozyme of fetal 
liver became only one of two arginase components detected in the adult where the new variant cross-reacted with antiserum against rat liver arginase and migrațed similarly to hepatic rat arginase. The single isozyme of fetal human liver was also the predominant variant of fetal human kidney (which also contained a trace of rat isozyme I). Electrophoresis had revealed that in fetal rat kidney, isozyme III, characteristic of rat liver, was the major component of young fetal kidney arginase and that it decreased around the time of birth to be replaced completely, in adult rat kidney, by isozymes I and II (8). Thus human hepatic arginase, like that of nonhepatic rat tissues but unlike that of rat liver, gained qualitative complexity with age.

It is difficult to compare the physiologic meaning of the enzymatic changes observed in human liver with those in the rat model. The developmental formation of many enzymes has been measured at frequent time intervals during gestation and the first neonatal month in the rat; it has thus been possible to correlate enzymic changes with physiologic events that occur as causes or consequences of the enzymatic modifications. In the human, tissue from only a brief span of the gestational period is available for biochemical testing. Furthermore, some of the morphologic changes which rat liver undergoes during fetal and neonatal development have been measured quantitatively $(3,7)$. Such morphometric techniques have not been applied to human tissue samples. Enzymatic determinations in human fetal livers therefore cannot be associated at this time with quantitative morphologic changes on the cellular or subcellular level.

\section{SUMMARY}

1. The developmental emergence or decline of glutamate dehydrogenase, alanine aminotransferase, arginase, and thymidine kinase activities in human liver resembles that of rat liver in that those enzymes at high levels prenatally in rat are also at significant levels in fetal human liver and the one enzyme not found in rat liver until 3 weeks after birth (alanine aminotransferase) is essentially absent from the fetal human liver.

2. Significant qualitative differences between human and rat liver occur with maturation. The adult human liver contains soluble as well as particulate forms of glutamate dehydrogenase and thymidine kinase. Neither soluble glutamate dehydrogenase nor particulate thymidine kinase is found in fetal human liver or, at any time, in rat liver. Arginase, which in rat liver maintains the same isozyme throughout life, in human liver develops a second isozyme after the fetal period. The isozyme of fetal human liver is identical with that of fetal human kidney and persists as a fraction of the total arginase in adult human liver. The isozyme formed later in human liver migrates similarly to the rat hepatic isozyme during electrophoresis and cross-reacts with antiserum against rat liver arginase.

3. The increased variety of forms of glutamate dehydrogenase, thymidine kinase, arginase, and alanine aminotransferase in adult human liver indicates the complexity of sequential gene activation in man.

\section{REFERENCES AND NOTES}

1. Gonzalez. A. W. A.: The prenatal growth of the albino rat. Anat. Rec., 52: 117 (1932).

2. Greengard, O.: Enzymic and morphological differentiation of rat liver. In: J. Dancis and J. C. Hwang: Perinatal Pharmacology: Problems and Priorities, p. 15 (Raven Press, New York, 1974).

3. Greengard, O., Federman, M., and Knox, W. E.: Cytomorphometry of developing rat liver and its application to enzymic differentiation. J. Cell Biol., 52: 261 (1972).

4. Greengard. O., Sahib, M. K., and Knox, W. E.: Developmental formation and distribution of arginase in rat tissues. Arch. Biochem. Biophys., 137: 477 (1970).

5. Herzfeld, A.: The distribution of glutamate dehydrogenase in rat tissues enzyme. 13: 246 (1972).

6. Herzfeld, A.: The developmental formation of pyrroline-5-carboxylate metabolising enzymes and of arginase in rat tissues. (In preparation.)

7. Herzfeld, A., Federman, M., and Greengard, O.: Subcellular morphometric and biochemical analyses of developing rat hepatocytes. J. Cell Biol.. 57: 475 (1973).

8. Herzfeld, A.. and Raper, S. M.: The heterogeneity of arginases in rat tissues. Biochem. J., 153: 469 (1976)

9. Knox, W. E.: Enzyme Patterns in Fetal, Adult and Neoplastic Rat Tissues, p. 335 (S. Karger, Basel. 1972).

10. Lowry, O. H.. Rosebrough, N. J., Farr, A. L., and Randall, R. J.: Protein measurement with the Folin phenol reagent. J. Biol. Chem., 193: 265 (1951).

11. Machovich, R., and Greengard, O.: Thymidine kinase in rat tissues during growth and differentiation. Biochim. Biophys. Acta, 286: 375 (1972).

12. Raihä, N. C. R., and Suihkonen, J.: Development of urea-synthesizing enzymes in human liver. Acta Pediat. Scand., 57: 121 (1968).

13. Reddi, P., Knox, W. E., and Herzfeld, A.: Types of arginase in rat tissues. Enzyme, 20: 305 (1975).

14. Rosen, F., Roberts. N. R., and Nichol, C. A.: Glucocorticosteroids and transaminase activity. I. Increased activity of glutamic-pyruvic transaminase in four conditions associated with gluconeogenesis. J. Biol. Chem.. 234: 476 (1959).

15. Segal. H. L.. Beattie. D. S., and Hopper, S.: Purification and properties of liver glutamic-alanine transaminase from normal and corticoid-treated rats. J. Biol. Chem., 237: 1914 (1962).

16. Taylor, A. T., Stafford, M. A., and Jones, O. W.: Properties of thymidine kinase partially purified from human fetal and adult tissue. J. Biol. Chem.. 247: 1930 (1972).

17. The protocol for the research on fetal livers was approved by the Research Advisory Committee of the Boston Hospital for Women.

18. This research was supported by United States Public Health Service Grant no. HD 04532 from the National Institute of Child Health and Human Development and Grant no. RR0559l awarded by the General Research Support Program. Division of Research Resources, Department of Health, Education and Welfare, and in part by the Division of Research of the Lahey Clinic Foundation (Grant no. 0683)

19. Requests for reprints should be addressed to: Dr. A. Herzfeld, Cancer Research Institute, New England Deaconess Hospital, 194 Pilgrim Rd., Boston, Mass. 02215 (USA)

20. Accepted for publication June 4, 1976. 